\title{
Persepsi Hakim Tentang Positivisasi Lembaga Rechtverwerking
}

\author{
Muhyidin \\ Fakultas Hukum Universitas Dipoenegoro, Jl. Prof. Soedarto No. 1 Tembalang, Semarang \\ Email : muhyidin85@yahoo.com
}

\begin{abstract}
When the law is unwritten, morality and ethics are registered in the form of laws, there will be a shift in the essential meaning of unwritten law, morality or ethics, because by unpostitiated the values of morality, unwritten ethics and law no longer devote itself to values, awareness and common interests, but serving those who have stronger "power", for example, the institution of rechtverwerking positivisation of the institution was originally intended to overcome the lack of a negative system in the land registration system, but then in the perspective of "Critical Legal Study" and the perception of judges who all positivistic makes the adat institution precisely castrate the rights of indigenous peoples over their customary land tenure.
\end{abstract}

Key Word : Perception, Positivisation of Institutions, Rechtverwerking

\begin{abstract}
Abstrak
Ketika hukum tidak tertulis, moralitas serta etika dipositivikasi dalam bentuk undangundang, maka akan terjadi pergeseran makna esensial dari hukum tidak tertulis, moralitas ataupun etika tersebut, sebab dengan dipositivisasi nilai moralitas, etika serta hukum tidak tertulis tersebut tidak lagi mengabdikan dirinya kepada nilai, kesadaran dan kepentingan bersama, tetapi mengabdi kepada mereka yang memiliki "kekuasaan" yang lebih kuat. Demikian misalnya lembaga rechtverwerking positivisasi lembaga ini semula dimaksudkan untuk mengatasi kekurangan sistem negatif dalam sistem pendaftaran tanah, namun kemudian dalam perspektif "Critical Legal Study" serta persepsi hakim yang serba positivistik menjadikan lembaga adat tersebut justru mengebiri hak masyarakat adat atas penguasaan tanah adat mereka
\end{abstract}

Kata Kunci : Persepsi, Positivisasi Lembaga, Rechtverwerking

\section{PENDAHULUAN}

Menurut lintasan sejarah, pembedaan dan pemilahan konseptual antara hukum dan masyarakat, sebenarnya terkait dengan perubahan-perubahan kondisi sosial-politik yang terjadi di Eropa Barat. Tumbuh kembangnya negara-negara nasional berteritori di 
bagian benua ini diiringi dengan kebutuhan akan suatu tertib hukum baru yang dasar legitimasinya tak lagi cukup ditumpukan pada asas-asas moral-religius yang implisit atau institusi-institusi sosial informal. Dari sinilah awal mula positivisasi hukum itu dirasakan sebagai kebutuhan, yang secara analitik dibedakan dengan tertib masyarakat. $^{1}$

Positivisasi hukum itu, kini telah merambah ke Indonesia Kompleksitas kehidupan, terutama sebagai akibat pengaruh kapitalisme, telah menyebabkan kompleksitas pula pada konfigurasi institusional hukum kita. Dalam situasi ini menjadi benar apa yang dikatakan Black ${ }^{2}$ bahwa law varies directly with organization. Walaupun demikian, masih dipertanyakan pula, benarkah di Indonesia secara keseluruhan sudah ada a movement from status to contract sebagaimana digambarkan oleh Maine, mengingat keberadaan masyarakat adat maupun hukum adat yang tetap eksis dan diakui oleh hukum nasional ${ }^{3}$ Fenomena yang dapat ditangkap adalah, ketika ada kebutuhan untuk mewujudkan kepastian hukum dan kepastian hak atas tanah semakin mendesak, maka telah ada positivisasi lembaga rechtverwerking, (sebuah lembaga hukum yang berasal dan berlaku pada hukum adat). Fenomena ini bermula ketika diselenggarakan kegiatan Pendaftaran Tanah. Pokok-pokok pendaftaran tanah itu diatur Pasal 19 UUPA. Selanjutnya, pelaksanaan pendaftaran tanah itu secara operasional diatur dalam PP No.10 Tahun 1961 tentang Pendaftaran Tanah, yang kemudian disempurnakan dengan PP No.24 Tahun 1997 (LN Rl 1997 No.59, TLNRI 3696).

Dalam UUPA Pasal 19 ayat (2) huruf c, dinyatakan bahwa pendaftaran tanah itu meliputi : “. . pemberian surat-surat tanda bukti hak yang berlaku sebagai alat pembuktian yang kuat”. Dalam Pasal 23, 32 dan 38 juga dinyatakan bahwa “. . . pendaftaran mempakan alat pembuktian yang kuat".

Ketentuan-ketentuan di atas mengandung pengertian bahwa Pendaftaran Tanah yang diselenggarakan itu sistem publikasinya negatif. Namun demikian, menurut Boedi Harsono, ${ }^{4}$ sistem negatif yang dianut UUPA itu mengandung unsur-unsur positif.

\footnotetext{
1 Baca : Soetandyo Wignjosoebroto, HUKUM, Paradikma, Metode dan Masalahnya, Elsam-Huma, Jakarta, 2002., h17.

${ }^{2}$ Baca : Donald Black, The Behaviour of Law, New York: Academics Press, 1976.p.86

${ }^{3}$ Baca : Sir Henry S.Maine, The A, The Ancient Law, London: Dent \& Sont, 1861.p.75.

${ }^{4}$ Baca: Boedi Harsono, Kelemahan Pendaftaran Tanah Dengan Sistem Publikasi Negative, Makalah Pada Seminar Nasional "Sejauhmana Kemungkinan Ke-Efektifan Pasal 32 PP No.24/1997 Dalam
} 
Kelemahan utama sistem publikasi negatif, bahwa pendaftaran tidak menciptakan hak yang tidak dapat diganggu gugat. Sah atau tidaknya suatu hak serta peralihannya ditentukan oleh sah atau tidaknya perbuatan hukum yang dilakukan, dan bukan oleh pendaftarannya. Oleh sebab itu, biarpun suatu hak atas tanah sudah didaftar dalam buku tanah dan diterbitkan sertifikatnya, masih selalu terbuka kemungkinan subyek yang terdahar dalam sertifikat itu kehilangan tanahnya, karena gugatan pemegang hak yang sebenarnya (nemo plusyuris).

Di negara Belanda (termasuk Hindia Belanda), kelemahan sistem "Publikasi negatif itu diatasi dengan menggunakan lembaga "vcrjaring”, yaitu karena lampaunya waktu, maka pihak yang menguasai tanah menjadi pemiliknya: (KUHPdt Ps.584 jo.1963) ; sementara itu dinegara-negara bagian Amerika Serikat, diatasi dengan menggunakan lembaga "adverse possession", yaitu kalau sebidang tanah diperoleh dengan itikad baik dan Sudah dikuasai sekian lama secara terbuka tanpa ada fihak yang menggugat, maka oleh hukum siapa yang menguasainya ditetapkan sebagai pemiliknya

Pasal-pasal KUHPdt mengenai lembaga verjaring sudah dicabut oleh UUPA. Lembaga vcrjaring yang hanya berlaku untuk tanah-tanah barat itu. menurut Putusan Hoog Gerechts Hof, 25 Oktober 1934 tidak dijumpai dalam hukum adat. Dalam rangka mengatasi kelemahan sistem publikasi negatif, lembaga "rechtsverwerking" yang dikenal dalam hukum adat "dipositifkan", yaitu diangkat menjadi hukum nasional yang tertulis dan bersifat universal, Di dalam PP No.24/ 1997, Pasal 32 ayat (2) dinyatakan bahwa : “. . . dalam hal atas suatu bidang tanah sudah diterbitkan sertifikat secara sah atas nama orang atau badan hukum yang memperoleh tanah tersebut dengan itikad baik dan secara nyata menguasainya, maka pihak lain yang merasa mempunyai hak atas tanah itu tidak dapat lagi menuntut pelaksanaan hak tersebut, apabila dalam jangka waktu 5 (lima) tahun sejak diterbitkannya sertifikat itu tidak mengajukan keberatan secara tertulis kepada pemegang senifikat dan Kepala Kantor Pertanahan yang bersangkutan ataupun tidak mengajukan gugatan ke pengadilan mengenai penguasaan tanah atau penerbitan sertifikat tersebut".

Menurut penjelasan PP tersebut, diposititkannya lembaga rechtsverwerking ini. bukanlah dimaksudkan untuk meniadakan eksistensinya dalam hukum adat, tetapi 
sebagai salah satu sarana pelengkap untuk mengatasi kelemahan sistem publikasi negatif, dengan cara memberikan perlindungan hukum kepada pemegang hak atas tanah. Dalam kerangka pemikiran dan analisis hukum kritis, tentu saja, Penjelasan seperti itu tidak bisa diterima begitu saja, mengingat bahwa di balik pembentukan sebuah perundang-undangan senantiasa ada kepentingan-kepentingan sosial, politik atau ekonomi para actor penggagas dan pembentuknya. Sehubungan dengan maksud dan tujuan Positivisasi lembaga rechtsverwerking yang tertuang dalam penjelasan itu, ada beberapa persoalan hukum yang muncul dan perlu mendapatkan perhatian :

1. Sebagai lembaga yang berasal dari hukum tak tertulis penerapan dan pertimbangan mengenai terpenuhinya persyaratan yang bersangkutan dalam kasus-kasus konkret ada di tangan hakim yang mengadili sengketanya;

2. Sebagaimana halnya lembaga verjaring hakim tidak dibenarkan menerapkannya apabila tidak diajukan sendiri oleh yang berperkara;

3. Para pelaksana (Aparatur Pertanahan) dI daerah umumnya meragukan efektifitas (atau dipatuhinya oleh hakim yang mengadili sehubungan dengan rechtsverwerking itu.

4. Di kalangan para ahli hukum juga terdapat keraguan serupa karena hakim tidak mwajib tunduk pada putusan hakim terdahulu; dan

5. Tidak tersedia lembaga asuransi (title asurance) sebagaimana dikenal di negaranegara yang menganut sistem publikasi positif.

Dari permasalahan-pennasalahan di atas, terlihat adanya peran yang dominan dan' seorang hakim dalam mengadili kasus rechtsverwerking. Di sini persepsi hakim, sebagai wawasan subyektif tentang positivisasi lembaga rechtsverwerking itu akan sangat besar pengaruhnya terhadap sikap dan perilaku maupun keputusankeputusannya. Apabila pola pikir hakim masih Iegal-positivistik, maka positivisasi lembaga rechtsverwerking akan diterimanya sebagai sebuah peraturan-perundangan baru dalam mengadili perkaranya. Ini berarti konsep hukum adat akan ditinggalkannya. Akan tetapi, bagi seorang hakim yang berwawasan luas, dia akan menaruh rasa curiga terhadap positivisasi lembaga rechtsverwerking itu, siapa dan kepentingan politik, ekonomi, sosial apa yang ada di balik positivisasi lembaga itu. Dengan kata lain, persepsi hakim menjadi dominan terhadap dihasilkannya keadilan formalistis ataukah keadilan substantif. 
Pengalaman selama ini menunjukkan bahwa pola pikir legal-positivistik, cenderung menghasilkan keadilan formalistis belaka. Siapa yang bisa bermain dengan hukum positif yang penuh formalitas dan prosedural akan dimenangkan. Biasanya, golongan elit, penguasa atau pengusaha yang bisa bermain dalam kancah ini, Inilah yang menjadi keprihatinan penegakan hukum di Indonesia. Hakim, sebenarnya punya kebebasan untuk menentukan pertimbangan-penimbangan hukum dalam mengadili suatu perkara. Ketentuan hukum positif bisa dikesampingkan apabila diyakini hal itu akan menjauhkan dari keadilan substantif. Seperti berbagai kasus rechtsverwerking sebelumnya, hakim cenderung berkiblat pada hukum adat, sebagai basis dari lembaga tersebut. Ini jauh dirasakan lebih adil. Bagi seorang hakim yang kritis, tentu tidak akan ragu-ragu mengambil hukum adat sebagai dasar pertimbangan memutus perkara rechtsverwerking itu. Kajian ini ingin melihat positivisasi lembaga rechtsverwerking itu pada dua hal. Pertama, bagaimana persepsi hakim terhadap positivisasi itu sendiri Kedua, adakah keberanian hakim menggunakan analisis hukum kritis dalam mengadili kasus rechtsverwerking itu?

\section{PEMBAHASAN}

\section{Lembaga Rechtsverwerking}

Menurut hukum adat. eksistensi lembaga rechtsverwerking tidak bisa dipisahkan dari konsep hak dan konsep hubungan. Hak adalah sesuatu yang nisbi atau relatif, sedangkan hubungan adalah hal yang nyata/konkrit, bersifat tatap bahkan abadi. Dengan demikian hak atas tanah dapat berubah-ubah, akan tetapi hubungan berupa ikatan antara manusia dengan tanah merupakan dua unsur yang berjiwa, tidak berubah dan harus terus dipertahankan.

Hak baru lahir karena adanya pengakuan atas hubungan nyata yang terjadi. baik oleh kesatuan organisasi, kesatuan masyarakat maupun oleh tetangga ataupun kerabat keluarga yang mengaku diri mereka sebagai anggota persekutuan. Jadi hubungan lahir karena adanya suasana batin yaitu rasa cocok atau tidak, sedangkan hak dilahirkan berdasarkan kenyataan penguasaan nyata yaitu tetap atau sementara penguasaan oleh orang-orang atau kelompok tertentu atas tanah yang diakuinya. Oleh karena itu hubungan bersifat tetap, sedangkan hak bersifat semu / berubah. Kuat dan langgengnya 
hubungan inilah yang menimbulkan hubungan hukum (rechtsbetreking) antara manusia dengan tanah, yang di dalamnya terdapat hak dan kewajiban.

Atas dasar pemahaman konsep hak dan hubungan seperti di atas, maka adanya hubungan magis antara manusia dengan tanah hanya dapat diakhiri, dilepas atau diputus, tetapi tidak dapat dihilangkan. Pemutusan hubungan itu dapat dinyatakan langsung (misal melalui pernyataan kehendak yang lembaga "adverse possesion" atau "verjaring" dan lembaga "title Insurance". Bahkan secara substansi lembaga "rechlsverwerking" adalah sama dengan lembaga "adverse possesion" atau lembaga perolehan hak karena kadaluwarsa", meskipun dalam konotasi dengan itikad tidak baik (bad faith). Perbedaannya hanya terletak pada penggunaan bersangkutan kepada warga masyarakat dan penguasa organisasi masyarakat) maupun tidak langsung (misal melalui tindakan membiarkan tanah tidak dirawat/diterlantarkan).

Dengan demikian perlu ditegaskan bahwa hukum adat tidak mengenal arti kehilangan hubungan atau kehilangan hak atas tanah. Dalam konsteks ini pemutusan hubungan magis antara individu /pemegang hak atas tanah dalam persekutuan hukum. Inilah yang oleh Ter Haar ${ }^{5}$ disebut rechtsverwerking. Ter Haar menggunakan istilah rechtsverwerking dalam dua cara : Pertama, dalam hubungan dagang; dan kedua, dalam hubungan pengaruh lamanya waktu.

Lembaga rechtsverwerking sebagai lembaga rekognisi hak akibat pengaruh lampaunya waktu tidak berdiri sendiri, melainkan menjadi satu kesatuan konsep dengan lembaga tersebut. Lembaga rechtsverwerking didefinisikan sebaliknya, yaitu lampaunya waktu yang menyebabkan orang menjadi kehilangan haknya atas tanah yang semua dimilikinya, maka lembaga ini digunakan untuk mempertahankan kepemilikan yang telah terdaftar dalam daftar umum. Di lain pihak, lembaga adverse possesion atau verjaring adalah lampaunya waktu yang menyebabkan otang menjadi mempunyai hak atas tanah yang semua dimiliki orang lain, maka lembaga ini digunnakan untuk memperoleh pendaftarannya dalam daftar umum.

Di dalam PP No.24 Tahun 1997 tentang Pendaftaran Tanah, lembaga rechtsverwerking ini akan digunakan sebagai alat atau sarana untuk mengatasi sistem negatif pendaftaran tanah. Lembaga ini dalam yurisprudensi dinyatakan dan diterapkan dalam berbagai keputusan pengadilan. Kalau dengan lembaga verjaring pihak yang

\footnotetext{
${ }^{5}$ Ter Haar, Bzn, 1994, h.45, 236
} 
menguasai tanah karena lampaunya waktu menjadi pemiliknya, dengan lembaga rechtsverwerking terjadi sebaliknya. Pihak yang mempunyai tanah karena lampaunya waktu kehilangan hak untuk memperoleh kembali haknya itu. Penerapan dan pertimbangan mengenai terpenuhinya persyaratan lembaga ini dalam kasus-kasus konkret berada ditangan hakim yang mengadili sengketanya. Hakim, tidak dibenarkan menerapkannya apabila tidak diajukan sendiri oleh yang berperkara (Pasal 1950 KUHPdt dan Putusan MA tgl.21 November 1958 No.361/K/Sip).

Dalam Penjelasan Pasal 32 ayat 2 PP No.24 Tahun 1997 antara lain disebutkan : “. . . ketentuan ini bertujuan pada satu pihak tetap berpegang pada sistem publikasi negatif dan pada lain pihak untuk secara seimbang memberikan kepastian hukum kepada pihak yang dengan itikad baik-baik menguasai sebidang tanah dan didaftar sebagai pemegang hak dalam buku tanah, dengan sertifikat sebagai tanda buktinya, yang menurut UUPA berlaku sebagai alat pembuktian yang kuat. Dalam hukum adat jika seseorang selama sekian waktu membiarkan tanahnya tidak dikerjakan, kemudian tanah itu dikerjakan orang lain yang memperolehnya dengan itikad baik, maka hilanglah haknya untuk menuntut kembali tanah tersebut. Ketentuan di dalam UUPA yang menyatakan hapusnya hak atas tanah karena diterlantarkan (Pasal 27, 34, dan 40) adalah sesuai dengan lembaga ini. Dengan pengertian demikian, maka apa yang ditentukan dalam ayat ini bukanlah menciptakan ketentuan hukum baru, melainkan merupakan penetapan ketentuan hukum yang sudah ada dalam hukum adat, yang dalam tata hukum sekarang ini mempakan bagian dari Hukum Tanah Nasional Indonesia dan sekaligus memberikan wujud konkrit dalam penerapan ketentuan dalam UUPA mengenai penerlantaran tanah".

\section{Karangka Analisis Hukum Kritis ${ }^{6}$}

CLS adalah nama payung bagi suatu arus pemikiran di kalangan ahli hukum di Amerika Serikat yang tidak puas dan menantang pemikiran hukum liberal yang sudah mapan dalam studi-studi hukum. Ada berbagai varian di dalam arus pemikiran ini, tetapi mereka dipersatukan oleh ketidakpuasan dan kritik-kritik mereka yang mendasar

\footnotetext{
${ }^{6}$ Dalam rangka memahami kerangka analisis hokum CLS ini selain perlu membaca buku dari para tokohnya (seperti: Unger, Kayris dan Duncan Kennedy),tulisan Ifdhal Khasim dalam "Sumber Daya ALam Untuk Rakyat", Elsam, 2000, sangat membantu. Uraian tentang CLS ini banyak bersumber dari tulisan itu.
} 
terhadap pendekatan dan doktrin hukum liberal. Paling tidak ada tiga varian utama di dalamnya. Pertama, adalah varian yang diwakili oleh Roberto M. Unger Varian ini mencoba mengintegrasikan dua paradigma yang saling bersaing, yakni paradigma konflik dan paradigma consensus. ${ }^{7}$ Kedua, varian yang diwakili oleh David Kairys, yang mewarisi tradisi pemikiran hukum Marxis atau tepatnya mewarisi kritik Marxis terhadap hukum liberal yang hanya dianggap melayani sistem kapitalisme. ${ }^{8}$ Ketiga, varian yang diwakili oleh Duncan Kennedy yang menggunakan metode ekletktis yang membaurkan sekaligus perspektif strukturalis, fenomenologis dan neo-marxis. ${ }^{9}$

Meskipun beragam dalam pendekatannya, para ahli hukum yang tergabung dalam CLS dipersatukan oleh kesamaan kritik mereka terhadap teori hukum liberal (liberal Iegalism). Apa yang dimaksud dengan liberal di sini adalah teori-teori hukum yang berakar dari tradisi filsafat pencerahan yang ditokohi oleh JJ Rousseau, dan sekarang mendapat aksentuasi melalui karya-karya Lon Fuller, ${ }^{10}$ Rawl ${ }^{11}$ dan Dworkin. ${ }^{12}$

Inti pemikiran hukum liberal adalah membangun teori tentang pemisahan hukum dengan politik (law-politics distinction) dan otonomi atau netralitas proses hokum (neutrality of law). Kira-kira yang dimaksud jargon-jargon itu adalah, bahwa hukum dan politik mempunyai jalannya sendiri-sendiri. Kalau hukum didasarkan pada asas yang diputuskan secara obyektif, sebaliknya politik diputuskan dengan sangat subyektif. Maka proses interpretasi (penerapan) hukum harus menghindarkan diri dari penilaian terhadap nilai-nilai yang bersaing yang menjadi kompetensi arena politik. Persis seperti yang ditandaskan Dworkin, salah seorang wakil kontemporer dari tradisi ini, yang menyatakan, "law Is based 'objective' decisions of principle, while politics depends on 'subjective' decisions aof policy". ${ }^{13}$

Pemikiran-pemikiran pokok dalam teori hukum liberal itulah yang persisnya ditampik dengan keras oleh kalangan CLS. Kalau ingin diringkas garis-garis besarnya

\footnotetext{
${ }^{7}$ Untuk mendlami pendapat Unger ini, layak dibaca karya-karyanya: "Knowledge and Politics" (1975); "Law in Modern Society: Toward a Critism of Social Theory" (1976); "The Critical Legal Studies Movement" (1986); "Politics: A Work in Contructive Social Theory" (1987); dan "False Necessety" (1987).

${ }^{8}$ Karya terpenting dari David Kairys adalah "Politics of Law", Pantheon Book, New York.

${ }^{9}$ Karya-karya Kennedy yang penting dibaca, antara lain: "The Strukture of Blackstone's Commentaries," Bufflo Law Review, 28, 1979; dan "Form and Subtance in Private Law Adjudication", Havard Law Review, 89, 1979.

${ }^{10}$ Salah satu karya terpenting Fuller adalah "The Morality of Law”, 1964

${ }^{11}$ Karya Jhon Rawl terpenting adalah "A Theory of Justice”, 1971

12 Salah satu karya terpenting dari Ronald Dworkin adalah "Taking Rights Saeriously; Law's Empire".

${ }^{13}$ Baca: Ronald Dworkin, "A Matter of Principle”, Havard University Press, Cambridge, 1985.
} 
kritik tersebut, tersimpul dalam tudingan mereka yang sangat pedas terhadap bangunan teori hukum liberal yang dikatakan mereka sebagai "incoherent", "internally inconsistent", dan "selfcontradictory" 14 Mengapa dikarakterkan demikian, karena menurut mereka proses-proses hukum bekerja tidak seperti dikontruksikan dalam doktrin hukum liberal sebagai netral dan obyektif. Tetapi bekerja dalam realitas yang tidak netral dan nilai yang ada di belakangnya adalah subyektif. Makanya terjadi inkonsistensi secara internal di dalam struktur doktrin hukum liberal itu sendiri. Contohnya adalah doktrin rule of law, yang sering menjadi sasaran kritik CLS. Doktrin ini dianggap sebagai mitos, karena tidak mungkin dapat diterapkan dalam realita.

Sebagai akibat adanya "self contradiction" atau "incoherent" di dalam struktur internal pemikirannya (doktrin), pendekatan yang dikembangkan oleh hukum liberal tidak membawa kita memahami secara koheren hubungan antara aturan di satu pihak dengan nilai-nilai di pihak lainnya. Persis seperti dikatakan Roberto M.Unger, yang menyatakan bahwa teori hukum liberal membuat kita, "inability to arrive at a coherent understanding of the relations between rules and values In social life".

Kalangan CLS berangkat dari titik tolak yang berbeda dengan teori hukum liberal, bahwa bagi mereka "law ls as negotiable. subjective and policy-dependem as politics". Menurut kalangan CLS tidak mungkin memisahkan politik dan pilihan-pilihan etik dengan hukum berdasarkan argumen obyektifitas dan netralitas hukum, sebagaimana dikembangkan teoritisi hukum liberal. Dengan mengemukakan pendirian ini. kalangan CLS ingin mengedepankan analisis hukum yang tidak hanya bertumpu pada segi-segi doktrinal semata yang mengandalkan metode deduktif (lewat silogisme logika formal), tetapi juga dengan mempertimbangkan berbagai faktor di luar hukum seperti pengaruh-pengaruh faktor sosial-politik dan ekonomi dalam proses pembentukan dan aplikasi (interpretasi) hukum.

Dalam pandangan CLS, faktor-faktor yang disebutkan di atas sangat terkait dan berpengaruh. baik dalam proses pembentukan hukum (law making) maupun aplikasinya dalam kasus-kasus konkrit (law aplication). Hukum bukanlah ranah yang esoterik dari wacana moral, ekonomi, dan politik pada umumnya, Dengan titik tolak seperti ini tampak sangat sulit untuk membayangkan suatu netralitas dan obyektifitas hukum, apakah dalam proses pembentukannya maupun dalam interpretasinya, Jauh lebih dapat

\footnotetext{
${ }^{14}$ Argumen-argumen mengenai pokok ini dielaborasi dengan baik oleh Roberto M. Unger lewat bukunya “Knowledge and Politics", Free Press, New York, 1975
} 
diterima memandang hukum sebagai suatu produk yang tidak netral; karena senantiasa ada kapentingan-kapentingan tersembunyi yang difasilitasi oleh hukum.

Mengapa dikatakan demikian ? Di sini argumen Roberto M. Unger menjadi penting dikutip: "First, procedure is Imperable from outcome: every method makes certain legislative choices more likely than other... Second, each lawmaking system Itself embodies certain values; it incomperates a view of how power ought to be distributed in the society and how conflicts should be resolved". ${ }^{15}$

Dengan kata lain, menjadi penting dipahami bagaimana proses-proses pembuatan kebijakan hukum ternyata sangat rentan dipengaruhi oleh prosedur dan pilihan-pilihan legislatif; yang keduanya tidak bisa dilepaskan dari sistem pembuatan hukum di sebuah negara yang pada dirinya bersifat sarat nilai karena melibatkan proses perebutan kepentingan di dalam masyarakat dan bagaimana konflik-konflik yang ditimbulkamya diselesaikan.

Kalau metode yang dikembangkan Unger lebih menaruh perhatian pada prosesproses pembuatan hukum, sebaliknya Duncan Kennedy melalui metode "eklektis"-nya lebih mengkonsentrasikan pada upaya bagaimana mengungkapkan doktrin hukum diciptakan dan bagaimana ia telah berfungsi mengabsahkan suatu sistem sosial tertentu. Persisnya bagaimana Metode eklektis Kennedy ini dioperasikan, yang membaurkan sekaligus perspektif strukturalis, fenomenologis dan neo-marxis.

Secara ringkas metode eklektis itu dapat diuraikan, bahwa sebelum melakukan suatu analisis hukum diperlukan terlebih dahulu pemahaman yang memadai mengenai segi isi dan doktrinal hukum atau yang disebut "internal relation". Setelah itu barulah dikaitkan dengan realitas hubungan sosial, politik dan ekonomi atau yang disebut dengan "external relation". Karena ada perbedaan analitis antara materi dan struktur internal pemikiran hukum di satu pihak, dan variabel di luarnya yang kemungkinan bakal mempengaruhinya yakni aspek-aspek kehidupan sosial, ekonomi, dan politik di pihak lainnya. Pada saat mengkaitkan antara "internal relation" dengan segi "external relation", ketika itulah pendekatan elektis digunakan; terutama untuk memahami realitas hubungan sosial, politik dan ekonomi. Atau dalam kata-kata Kennedy sendiri: "We need to understand far more than we now do about the content and internal

\footnotetext{
${ }^{15}$ Baca: Roberto M. Unger, "Law in Modern Society”, Free Press, New York, 1976, p.180.
} 
structure of legal thought before we can hope to link it in any convincing way to other aspects of social, political or economic life ". ${ }^{16}$

Singkatuya dengan metode ini Kennedy ingin mengajak memahami signifikansi politik dibalik doktrin-doktrin hukum yang sekaligus akan mengungkapkan "hidden political intentions" di belakang eksposisi hukum. Pendekatan Kennedy membantu kita untuk memahami hubungan antara doktrin hukum dengan konteks politico-intelectual di balik doktrin tersebut.

Kiranya baik metode yang dikembangkan oleh Unger maupun yang dikembangkan Kennedy semakin menegaskan kepada kita, bahwa doktrin atau eksposisi hukum bukanlah sesuatu yang terisolasi dengan aspek-aspek sosial, politik dan ekonomi. Keduanya melihat bahwa hukum bukanlah sesuatu yang terjadi secara alamiah, melainkan merupakan resultante dari berbagai proses interaksi dan negosiasi berbagai kepentingan di antara faksi-faksi di dalam masyarakat dan negara. Dengan demikian, analisis untuk memahami hukum haruslah diarahkan kepada realitas kekuatan-kekuatan sosial-politik dan ekonomi di dalam masyarakat, atau dalam katakata Unger sendiri menyatakan:

"An understanding of the balance of force that produced the law, of the aim of the proponderant forces, and of the concessions they may have made to secure their objective, may all help. Rather than retrospective and rasionalistic reconstruction in the language of idealized policy and principle we have the attempt to understand law as the episode expression of practical compromise in the presence of real conflict; conflict of ideal visions as well as of material interest". ${ }^{17}$

Apa yang sesungguhnya dikembangkan CLS adalah suatu teori dengan kapasitas untuk memberikan analisis kausal mengenai doktrin legal dalam hubungan dengan relasi-relasi sosial-ekonomi tanpa mendasarkan diri pada determinisme apapun CLS menolak baik posisi otonomi hukum yang dikembangkan oleh teori hukum liberal maupun posisi determinisme hukum dari kalangan hukum Marxis.

Dari uraian di atas dapat dipahami bahwa metode analisis CLS sangat terbuka untuk kita gunakan menganalisis proses-proses hukum, baik pembentukan dan penerapannya, maupun untuk menganalisis suatu doktrin hukum dan bagaimana ia telah berfungsi mengabsahkan suatu sistem sosial atau kebijakan tertentu. Apabila hakim dalam mengadili suatu kasus rechtsverwerking berpihak pada kerangka berpikir aliran

\footnotetext{
${ }^{16}$ Baca: Duncan Kennedy, “The Stucture of Blackstone’s Commentaries”, Buffalo Law Review, 28,1979.

${ }^{17}$ Baca: Roberto M. Unger, "What Should Legal Analysis Become?", Verso, New York, 1996, p.53.
} 
hukum kritis, maka bisa dipastikan bahwa positivisasi lembaga tersebut bisa tidak berlaku secara efektif dalam masyarakat. Sebaliknya apabila, hakim tetap berpegang pada pola pikir positivistik, maka penguasaan tanah menurut hukum adat akan mudah dikalahkan dalam persidangan tersebut.

\section{SIMPULAN}

Apa yang hendak dinyatakan dan dibuktikan lewat kajian ini, bahwa positivisasi hukum tidak selalu bermakna baik untuk kehidupan masyarakat. Justru ada kecenderungan positivisasi itu lebih berpihak pada kepetingan-kepentingan golongan elit. Dalam kasus ini, melalui analisis hukum kritis, mereka yang berkepentingan dengan positivisasi lembaga rechtsverwerking itu adalah para penguasaha, baik dari dalam ataupun luar negeri. Keterlibatan mereka dalam proses positivisasi maupun pelaksanaan hukumnya, mungkin tidak secara langsung. Tetapi dengan berbagai kekuatan yang dimilikinya, mereka bisa mempengaruhi proses penyusunan maupun pelaksanaan hukum itu.

Seorang hakim, khususnya di Indonesia, memang tidak terikat untuk selalu mengedepankan pendekatan positivistik. Dia bebas menentukan berbagai pertimbangan hukum yang diyakininya akan lebih menghasilkan kadilan substantif. Ketentuan yang ada dalam perundang-undangan bisa saja disingkirkan, kalau hakim menaruh kecurigaan terhadap itikad baik para penggagas dan penyusun perundang-undangan tersebut. Kerangka berpikir seperti ini, akan bisa dimiliki oleh seorang hakim apabila ia memperluas wawasannya, bahwa setiap hukum senantiasa sarat dengan kepentingan sosial maupun politik, dan oleh karenanya tidak boleh dipercaya begitu saja sebagai hukum yang netral. Demi tercapainya keadilan substantif, maka apabila dirasakan suatu perundang-undangan sudah tidak netral lagi, maka ketidak-netralan itu harus diatasi dengan pemihakan kepada klien yang akan menjadi korbannya. 


\section{DAFTAR PUSTAKA}

Black,Donald, The Behavior of Law, New York: Academics Press, 1976.

Dworkin, Ronald., "T aking Rights Saeriously; Law 's Empire "., "A Matter of Principle",

Harvard University Press, Cambridge, 1985.

Harsono, Boedi,. 2002, Kelemahan Pendaftaran Tanah Dengan Sistem Publikasi Negatif,

Makalah pada seminar nasional "Sejauhmana Kemungkinan Ke-efektifan Pasal 32 PP No.24/1997 Dalam Mengatasi Kelemahan PT Dengan Sistem Publikasi Negatif', diselenggarakan PSHA FH, Univ.Trisakti, Jakarta, 20 Maret 2002.

Haar, Bzn,.1994, Asas-asas dan Susunan Hukum Adat, Terjemahan K.Ng.Soebakti Poesponoto, Penb.Pradnya Paramita, Jakarta.

Kasim, 1fdhal., "Sumber Daya Alam Untuk Rakyat", Elsam, 2000.

Kairys, David., "Politics of Law", Pantheon Book, New York.

Kennedy, Dunca., "The Structure of Blackstone 's Commentaries," Bumo Law Review, 28 ,

1979; dan "Form and Substance in Private WAdiudication", Harvard Law Review, 89, 1979.

Maine, Sir Henry S., The Ancient Law, London: Dent \& Sont, 1861.

Unger, Roberto M., "Knowledge and Politics" Free Press, New York, 1975.

-“The Critical Legal Studies Movement”, Free Press, New York 1986

_“Politics: A Work in Contmctive Social Theory“ Free Press, New York ,1987

“"False Necessely" "Free Press, New York, 1987.

“Law in Modem Society”, Free Press, New York, 1976.

Wignjosoebroto,Soetandyo., Perspektif Teoritik Para Perintis Sosiologi Hukum Eropa Dari

Masa Pertengahan Abad 19 Sampai Ke Masa Awal Abad 20, Dalam HUKUM, Paradigma, Metode dan Dinamikanya, Elsam , Jakarta, 2002. 